\title{
Comparison of Solar Radiation Estimation Methods Using Weather Parameters
}

\author{
M. Punitha* and R. Rajendran \\ AEC\&RI, Department of Land and Water Management Engineering, \\ Tamil Nadu Agricultural University, Kumlur, Trichy, Tamil Nadu, India \\ *Corresponding author
}

\section{A B S T R A C T}

Keywords

Reference crop evapotranspiration, Temperature, Solar radiation, Weather parameter.

\section{Article Info}

Accepted: 30 June 2017 Available Online: 10 November 2017
The aim of this study was to estimate solar radiation and reference crop evapotranspiration by using of limited weather parameters. This paper also describes the modification of the original equation with maximum and minimum temperatures for solar radiation. Thus, modifications involved for the corrections associated with climatological parameters and also to determine the accuracy and applicability of a number of existing and newly developed formulae for calculating solar radiation from other weather variables.

\section{Introduction}

$\mathrm{ET}_{0}$ plays an important role in scheduling of irrigation water. Several empirical and semi empirical methods have been developed over the last 50 years to estimate reference evapotranspiration.

The different methods catered for users with different data availability and requiring different levels of accuracy.

The FAO-56 Penman-Monteith (FAO-56 PM) method which requires numerous weather data: maximum and minimum relative air humidity, wind speed at $2 \mathrm{~m}$ height and solar radiation (sunshine hours). Hayhoe (1998) recently evaluated the empirical approaches for estimating solar radiation and compared them to stochastic weather generation. $\mathrm{He}$ found that an empirical model based on temperature and rainfall provided better estimates than the stochastic model.

\section{Materials and Methods}

$\mathrm{R}_{\mathrm{s}}=(\mathrm{KT})\left(\mathrm{R}_{\mathrm{a}}\right)(\mathrm{TD})^{0.5}$

$\mathrm{TD}=$ maximum daily temperature minimum daily temperature $\left({ }^{0} \mathrm{C}\right)$ for weekly or monthly periods,

$\mathrm{R}_{\mathrm{a}}=$ Extraterrestrial radiation ( $\mathrm{mm} /$ day) and

$\mathrm{KT}=$ empirical coefficient 
$\mathrm{ET}_{0}=0.0135(\mathrm{KT})\left(\mathrm{R}_{\mathrm{a}}\right)(\mathrm{TD})^{1 / 2}(\mathrm{TC}+17.8)$ (2)

$\mathrm{TD}=$ maximum daily temperature minimum daily temperature $\left({ }^{0} \mathrm{c}\right)$ for weekly or monthly periods,

$\mathrm{TC}=$ average daily temperature $\left({ }^{0} \mathrm{C}\right)$

Hargreaves (1994) recommended using KT = 0.162 for interior regions and $\mathrm{KT}=0.19$ for coastal regions.

Meteorological data were obtained for station (Aduthurai) Climatological parameters are presented in table. 1

\section{Results and Discussion}

Estimated solar radiation and $\mathrm{ET}_{0}$ for the observation period shows tremendous increase of value during the year of 1999.

Hence, basic goal attained by reliable estimation of $\mathrm{ET}_{0}$ only based on the temperature data.

Hargreaves (1994) recommended for using $\mathrm{KT}=0.162$ for interior regions and $\mathrm{KT}=0.19$ for coastal regions.

Fig.1 Estimated solar radiation over the year for the month of May

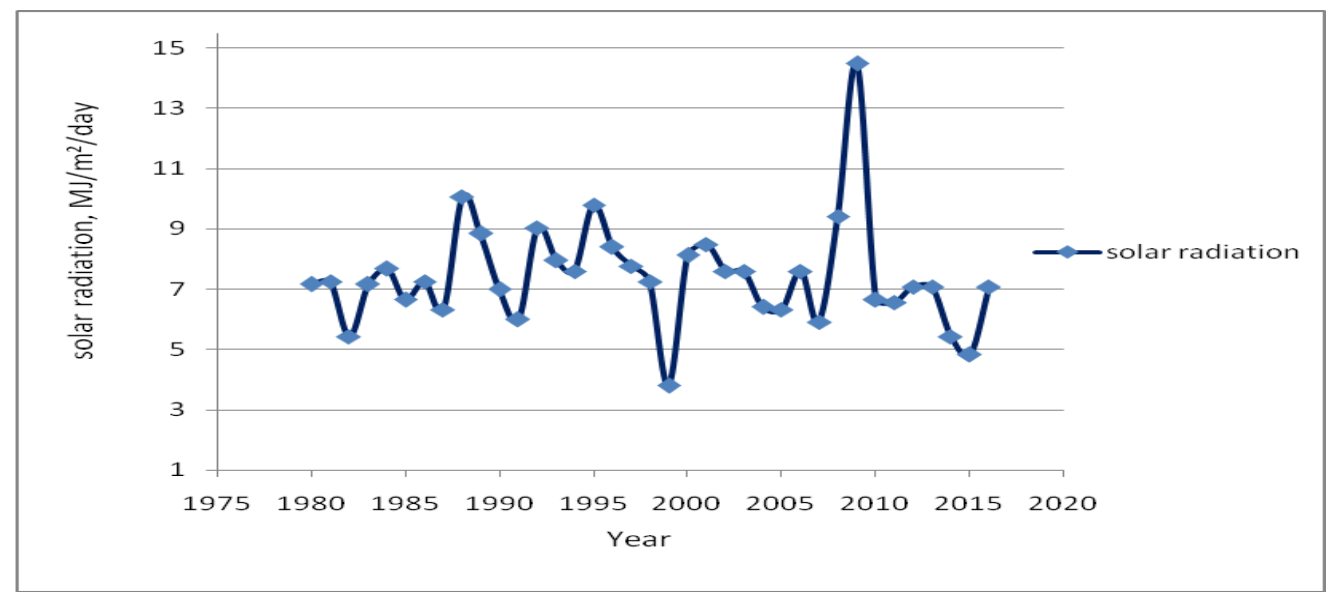

Fig.2 Estimated $\mathrm{ET}_{0}$ (Reference evapotranspiration) over the year for the month of May

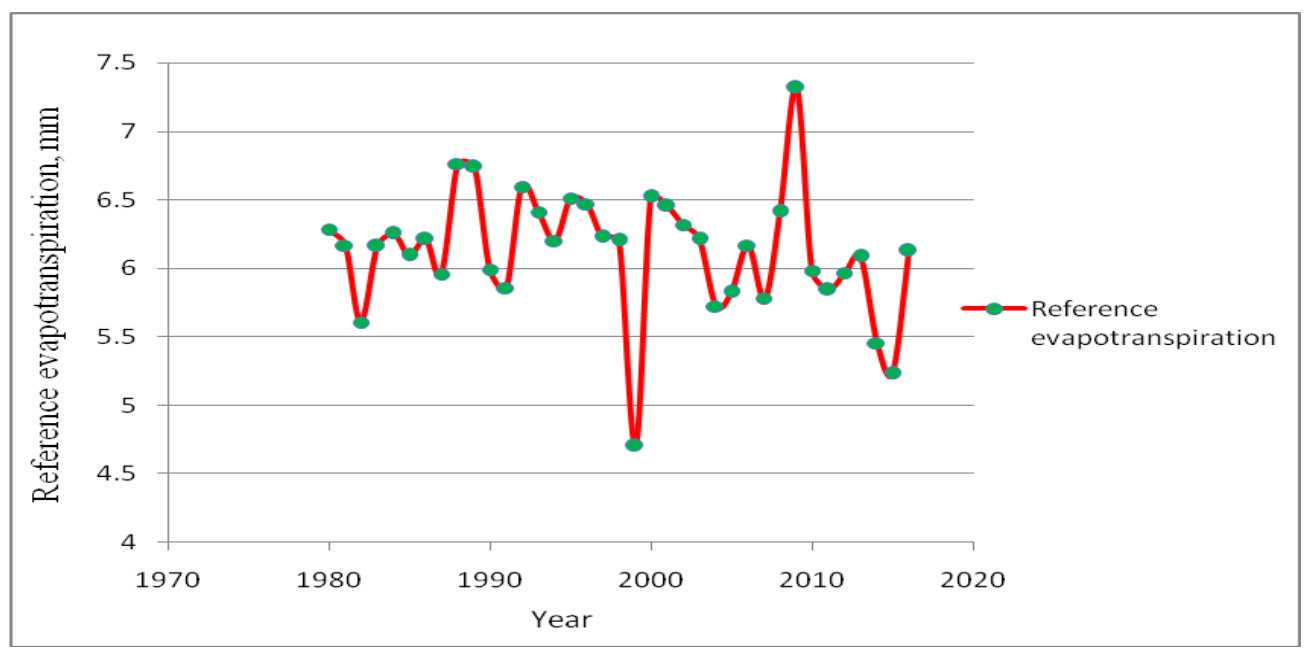


Table.1 Details about the location of study area

\begin{tabular}{|l|l|l|l|l|}
\hline Location & Latitude & Longitude & Elevation & Data record \\
\hline Aduthurai & $11^{\circ} 00^{\prime} 55^{\prime \prime} \mathrm{N}$ & $79^{0} 28^{\prime} 51^{\prime} \mathrm{E}$ & $20 \mathrm{~m}$ & $1980-2016$ \\
\hline
\end{tabular}

Table.2 Comparison between calculated and estimated values of KT

\begin{tabular}{|l|l|l|l|l|l|l|l|}
\hline Station & Elevation & TD $^{\mathbf{0}} \mathbf{C}$ & $\begin{array}{l}\text { KT Allen } \\
\text { estimated }\end{array}$ & $\begin{array}{l}\text { KT } \\
\text { estimated }\end{array}$ & $\begin{array}{l}\text { KT } \\
\text { calculated }\end{array}$ & $\begin{array}{l}\text { Percentage } \\
\text { of Error }\end{array}$ & $\begin{array}{l}\text { Percentage } \\
\text { of error }\end{array}$ \\
\hline Aduthurai & $20 \mathrm{~m}$ & 12.5 & 0.22 & 0.15 & 0.14 & $65 \%$ & $7 \%$ \\
\hline
\end{tabular}

Table.3 Statistical summary of $\mathrm{ET}_{0}$

\begin{tabular}{|l|l|l|l|}
\hline Method & MME & MAE & RMSE \\
\hline Penman-Monteith & 0.459 & 0.199 & 0.213 \\
\hline Hargreaves & 0.931 & 0.425 & 0.401 \\
\hline Thornthwaite & 0.566 & 0.375 & 0.317 \\
\hline
\end{tabular}

MME (Maximum absolute error); MAE (Mean absolute error); RMSE (Root mean square error)

Allen (1995) recommended a correction factor for KT. Allen (1996) suggested using $\mathrm{KT}=0.17\left(\mathrm{P} / \mathrm{P}_{0}\right)^{0.5}$ for interior regions and $\mathrm{KT}$ $=0.2\left(\mathrm{P} / \mathrm{P}_{0}\right)^{0.5}$ for coastal regions to account for proximity of large water body and elevation effects on the volumetric heat capacity of the atmosphere, where $\mathrm{P}=$ mean monthly atmospheric pressure of the site and $\mathrm{P}_{0}=$ mean monthly atmospheric pressure at sea level.

This study evaluated a method to estimate solar radiation by using of limited weather parameters such as maximum and minimum temperature. Maximum error obtained with the proposed modification in estimating solar radiation was $7 \%$.

Hargreaves and Thornthwaite overestimated the FAO- 56 Penman- Monteith value. Hargreaves and Thornthwaite estimated method recommended for $\mathrm{ET}_{0}$ of the peak month.

\section{References}

Allen, R.G., 1995. "Evaluation of procedures for estimating mean monthly solar radiation from air temperature." Report submitted to the United Nations Food and Agricultural Organization (FAO), Rome Italy.

Hargreaves, G.H., 1994. "Simplified coefficients for estimating monthly solar radiation in North America and Europe." Departmental Paper, Dept. of Biol. And Irrig. Engrg, Utah State University, Logan, Utah.

Hayhoe, H.N., 1998. Relationship between weather variables in observed and WXGEN generated data series. Agric. For. Meteoro/, 90: 203-214.

\section{How to cite this article:}

Punitha, M. and Rajendran, R. 2017. Comparison of Solar Radiation Estimation Methods Using Weather Parameters. Int.J.Curr.Microbiol.App.Sci. 6(11): 4235-4237. doi: https://doi.org/10.20546/ijcmas.2017.611.496 